\title{
Short-term Effects of Organic and Inorganic Fertilizers on Soil Properties and Enzyme Activities in Rice Production
}

\author{
L.K. Jat* and Y.V. Singh \\ Department of Soil Science and Agricultural Chemistry, Institute of Agricultural Sciences, \\ Banaras Hindu University, Varanasi- 221005 (U.P.), India \\ *Corresponding author
}

\section{A B S T R A C T}

A field study was carried out on Alluvial soils of Varanasi to analyse the short term impacts of replacing mineral by organic fertilizers on the physico-chemical properties and enzyme activities relevant for soil fertility and crop production. Three types of fertilization regimes were tested viz., no fertilizer, conventional as $100 \%$ RDF by inorganic fertilizer and combined integrated fertilizer in which $70 \%$ RDF with $30 \%$ of the nitrogen were

Keywords

Soil, Physicochemical properties, Microbial biomass carbon, Enzyme activity, Rice.

Article Info

Accepted:

12 January 2017

Available Online:

10 February 2017 supplied by either FYM or pressmud or vermicompost or combination of these two or all. In the experiment, application of $70 \%$ recommended dose of fertilizers (RDF) $+30 \% \mathrm{~N}$ supplied through FYM and pressmud improved soil $\mathrm{pH}$, organic carbon, cation exchange capacity, bulk density and water holding capacity of post harvest soil of rice. However, nutrient integrations with organic and inorganic sources had a non significant effect on electrical conductivity, CEC, BD and WHC of soil. Available N, P and K of soil were significantly affected by integrated nutrient treatments which showed up to $25.52,54.85$ and $29.87 \%$ increase of these nutrients over control, respectively. The DTPA extractable cationic micronutrients also increase significantly by combined application of organics and inorganic fertilizers. The highest microbial biomass carbon $\left(218.2 \mu \mathrm{g} \mathrm{g}^{-1}\right)$, urease activity (221.9 $\mu \mathrm{g}$ urea $\left.\mathrm{g}^{-1} \mathrm{~h}^{-1}\right)$, alkaline phosphatase $\left(121.5 \mu \mathrm{g} \mathrm{pNP} \mathrm{g}^{-1} \mathrm{~h}^{-1}\right)$ and dehydrogenase activity $\left(44.5 \mu \mathrm{g}\right.$ TPF $\left.\mathrm{g}^{-1} \mathrm{~d}^{-1}\right)$ recorded with treatment $70 \% \mathrm{RDF}$ with $30 \% \mathrm{~N}$ by FYM and pressmud equally. The study reveals the effects of the organic amendments were observed even when they involved a small portion of the total amount of nutrients supplied; thereby confirming that some of the beneficial effects of integrated fertilizer strategies may occur in the short term in rice production and the promising combination was $70 \%$ of recommended NPK combined with FYM and pressmud on basis of $30 \% \mathrm{~N}$ by produced the best response.

\section{Introduction}

Fertile soils are a fundamental asset for a sustainable rice-wheat cropping systems followed in $13 \mathrm{Mha}$ in the Indo-Gangetic plains (IGP). Managing practices for the ricewheat cropping system are changing and in turn influencing soil fertility parameters (Singh and Singh, 2012).
For over a decade, rice-wheat cropping system yields in IGP have either stagnated or declined. The most important reason is a decline in factor productivity resulting from depletion of soil fertility. The system commonly shows signs of fatigue and is no longer exhibiting increased production with higher input use based on the current pattern. 
Even with current generalized recommended rates of fertilization for this system, a negative balance of the primary nutrients exists (Shukla et al., 2005). Rice is the staple food crop for more than $70 \%$ of Indian people and is the main crop during rainy season in IGP (Mahajan et al., 2012). The practice of adopting a cereal-cereal cropping system on the same piece of land over years has led to soil fertility deterioration and questions are being raised about its sustainability (Singh et al., 2015).

It has been realized from long-term fertilizer experiments that neither inorganic fertilizers nor organic manures alone can achieve sustainability in production, whereas integrated use of organics as well as inorganic fertilizers are essential to improve soil health and enhance productivity and input use efficiency which can sustain a highly intensive cropping system. The positive effect of judicious use of organic manure and inorganic fertilizers on productivity of crops and soil fertility has been reported by many workers (Baishya et al., 2015; Singh et al., 2015 and Kundu et al., 2016)

Organic amendments such as recycling of agricultural wastes and application of organic manures have sustained crop production for several years before the introduction of inorganic fertilizers along with the entry of high yielding and fertilizer responsive cultivars that have largely replaced the traditional practices (Ramachandran and Biswas, 2016). However, there are many reports that the yield of crops are either stagnate or declined in recent years due to continuous application of mineral fertilizers alone (Sekhon et al., 2009; Scotti et al., 2015). The major reason behind this is the decline in soil organic carbon (SOC) which is considered as the most important factor in maintaining soil fertility and sustaining the productivity of agroecosystems ( $\mathrm{Su}$ et al.,
2006). Sharma and Subehiya (2014) viewed that integrated use of organic manure and chemical fertilizers would be quite promising not only in providing greater stability in production, but also in maintaining better soil fertility. It is generally believed that combining organics with inorganic fertilizer will increase synchrony and reduce losses by converting inorganic $\mathrm{N}$ into organic forms. The application of organic manures influences the physical and chemical properties of soil and enhances the biological activities (Kharche et al., 2013; Jat et al., 2015). It is also positively correlated with soil porosity and enzymatic activity (Srinivas et al., 2015).

Application of different organic manure in combination with chemical inorganic fertilizer to agricultural lands is a popular practice in crop production. However, little information is available on suitable combination of different organics with chemical fertilizer on the soil properties. Keeping in view above facts, the present investigation studies an integration of chemical fertilizer, organics i.e. FYM, pressmud, vermicompost and its influence on physico-chemical properties and enzyme activity in rhizospheric soil of rice in ricewheat cropping system.

\section{Materials and Methods}

\section{Study area}

The present investigation conducted at Agricultural Research Farm, Banaras Hindu University, Varanasi during kharif season of 2013 using paddy as test crop. The experimental site was located between $25.14^{0}$ to $25.33^{\circ} \mathrm{N}$ latitude and $82.56^{\circ}$ to $83.03^{\circ} \mathrm{E}$ longitudes and falls in a semi arid to sub humid climate. The mean ambient temperature and relative humidity during the experiment ranged from $17.3{ }^{0} \mathrm{C}$ to $34.8{ }^{0} \mathrm{C}$ and $75 \%$ to $86 \%$, respectively. 


\section{Characteristics of organic inputs}

Three organic inputs used under study viz., FYM, pressmud and vermicompost. The FYM had pH 7.42, EC $1.44 \mathrm{dS} \mathrm{m}^{-1}$, organic carbon $22.8 \%$, total $\mathrm{N}, \mathrm{P}, \mathrm{K}$ and $\mathrm{S}$ contents were $0.78,0.36,0.50$ and $0.18 \%$, respectively with C:N ratio 29.2:1. Vermicompost having $\mathrm{pH} 7.42$, EC $1.26 \mathrm{dS} \mathrm{m} \mathrm{m}^{-1}$, organic carbon $31.3 \%$, total $\mathrm{N}, \mathrm{P}, \mathrm{K}$ and $\mathrm{S}$ contents were $1.41,0.43,0.63$ and $0.42 \%$, respectively with C:N ratio 22.2:1. Similarly pressmud had $\mathrm{pH}$ 7.56, EC $1.58 \mathrm{dS} \mathrm{m}^{-1}$, organic carbon $35.0 \%$, total $\mathrm{N}, \mathrm{P}, \mathrm{K}$ and $\mathrm{S}$ contents were $2.0,1.78$, 0.42 and $2.28 \%$, respectively with $\mathrm{C}: \mathrm{N}$ ratio 17.5:1.

\section{Experimental design and treatment combination}

The experiment was conducted in randomized block design in three replications with 9 treatments. The treatments consisted of different organics which applied on nitrogen basis and inorganic fertilizer viz., $\mathrm{T}_{1^{-}}$Control (no fertilizer), $\mathrm{T}_{2}-100 \% \operatorname{RDF}$ (120:60:60), $\mathrm{T}_{3-}-70 \% \mathrm{RDF}+30 \% \mathrm{~N}$ by FYM, $\mathrm{T}_{4}-70 \%$ $\mathrm{RDF}+30 \% \mathrm{~N}$ by vermicompost (VC), $\mathrm{T}_{5}-$ $70 \% \mathrm{RDF}+30 \% \mathrm{~N}$ by pressmud $(\mathrm{PM}), \mathrm{T}_{6}-$ $70 \% \mathrm{RDF}+15 \% \mathrm{~N}$ by $\mathrm{FYM}+15 \% \mathrm{VC}, \mathrm{T}_{7}-$ $70 \% \mathrm{RDF}+15 \% \mathrm{~N}$ by $\mathrm{VC}+15 \% \mathrm{PM}, \mathrm{T}_{8}-$ $70 \% \mathrm{RDF}+15 \% \mathrm{~N}$ by $\mathrm{FYM}+15 \% \mathrm{PM}, \mathrm{T}_{9}-$ $70 \% \mathrm{RDF}+10 \% \mathrm{~N}$ by $\mathrm{FYM}+10 \% \mathrm{PM}+10 \%$ VC. Organic manures were applied before 15 days of transplanting.

\section{Soil analysis}

Soil was sampled manually from all the plots at $0-15 \mathrm{~cm}$ using a tube auger. Five subsamples per plot were taken and carefully mixed. Soil biological analyses were carried out on moist samples in triplicate and the results were expressed on a dry weight basis. The soil samples were collected after the harvest of rice crop. The soil samples were analyzed for $\mathrm{pH}$ in 1:2.5 soil: water suspension; bulk density and water holding capacity (Black, 1965), organic carbon by methods of Walkley and Black (1934); available $\mathrm{N}$ by alkaline potassium permanganate (Subbiah and Asija, 1956); $\mathrm{NaHCO}_{3}$ extractable-P (Olsen et al., 1954) by spectrophotometer, ammonium acetate extractable K (Hanway and Heidel, 1952) by flame photometer and $0.15 \% \quad \mathrm{CaCl}_{2}$ extractable $\mathrm{S}$ by developing turbidity using $\mathrm{BaSO}_{4}$ (Chesnin and Yien, 1950) and DTPA extractable $\mathrm{Fe}, \mathrm{Cu}, \mathrm{Mn}$ and $\mathrm{Zn}$ (Lindsay and Norwell, 1978) by atomic absorption spectrophotometer following the procedure outlined in Sparks (1996). The microbial biomass carbon of the soil was determined using the fumigation-extraction method of Vance et al., (1987). The levels of three enzymatic activities in soil were measured, urease activity by KCl-PMA solution (Douglas and Bremner, 1971), alkaline phosphatese activity by p-nitrophenyl phosphate (Tabatabai and Bremner, 1969) and dehydrogenase enzyme activity of soil by triphenyl tetrazolium chloride reduction method as described by Casida et al., (1964). The soil fertility dynamics of experimental field was estimated by soil analysis of composite soil sample from each plot before transplanting and after harvesting of crop. The soil of the experimental site was moderately alkaline in reaction with $\mathrm{pH} 8.4$, electrical conductivity $\left(0.23 \mathrm{dSm}^{-1}\right)$ medium in organic carbon $0.39 \%$, deficient in available nitrogen $\left(205.7 \mathrm{~kg} \mathrm{ha}^{-1}\right)$ medium in available $\mathrm{P}(29.36$ $\left.\mathrm{kg} \mathrm{ha}^{-1}\right)$ and medium in $\mathrm{K}\left(184.65 \mathrm{~kg} \mathrm{ha}^{-1}\right)$, medium in available $\mathrm{S}\left(11.45 \mathrm{mg} \mathrm{kg}^{-1}\right)$, and DTPA- extractable $\mathrm{Fe}, \mathrm{Cu}, \mathrm{Mn}$ and $\mathrm{Zn}$ was $35.53,2.31, \quad 9.42$ and $1.41 \mathrm{mg} \mathrm{kg}^{-1}$, respectively.

\section{Statistical analysis}

The data were subjected to one-way analysis of variance (ANOVA) using SPSS version 16 
software. Duncan's multiple range test (DMRT) was performed to test the significance of difference between the treatments.

\section{Results and Discussion}

\section{Physico-chemical properties of soil}

Both soil $\mathrm{pH}$ and EC values varied significantly among various treatments (Table 1). There was decrease in soil $\mathrm{pH}$ in all the treatments when compared to the initial values (8.40), where as EC values have increased from 0.23 (initial value) to 0.31 $\mathrm{dSm}^{-1}$ with treatment $\mathrm{T}_{8}$, however there was no significant difference among treatments. The values were fluctuating among the treatments which might be because of the dissolved salts contribution from soil, water and release of ionic species due to reduction process as reported by Sur et al., (2010). It was observed that the application of pressmud were found more effective than application of FYM in reducing soil $\mathrm{pH}$ and contributed more salts to increase EC in the soil after the harvest of rice and wheat (Singh et al., 2015). More availability of soluble forms of $\mathrm{K}, \mathrm{Ca}$, $\mathrm{Mg}$ and $\mathrm{Na}$ those lead to formation of some salts due to addition of organics, which might be responsible for the higher EC of the soil after harvest of the rice crop (Gogoi et al., 2015).

Organic carbon content has increased from 0.39 to $0.48 \%$ over initial level and from 0.36 per cent to $0.48 \%$ over control over the years in the treatments with organic sources of nutrients in addition to inorganic fertilizers (Table 1). The increase in organic carbon content in treatments with combination of both organic and inorganic sources may be attributed to higher biomass addition to soil through crop residues as per the observation of Sur et al., (2010). Lowering of organic carbon content of soil was common in control and in treatments with only inorganic fertilizers (Katkar et al., 2012). This type of lowering of organic carbon content of soil may be due to its rapid mineralization resulting from intensive cropping and also as a result of attaining stable equilibrium with the changing soil crop environment (Singh et al., 2008).

The results of the investigation showed that the cation exchange capacity (CEC) of the soil increased significantly over the control due to the application of organic manures in combination with chemical fertilizers. The higher value $\left(10.17 \mathrm{Cmol}\left(\mathrm{p}^{+}\right) \mathrm{kg}^{-1}\right)$ of CEC observed in with treatment $\mathrm{T}_{8}$. Soil organic matter and clay particles have large surface areas and have a large number of exchange sites. As a consequence of the application of organic amendments, which increase organic $\mathrm{C}$ stock and result is soil cation exchange capacity (CEC) increases (Scotti et al., 2015).

The bulk density (BD) and water holding capacity (WHC) not significantly affected by application of NPK + organics, however lowest value of $\mathrm{BD}\left(1.35 \mathrm{Mg} \mathrm{m}^{-3}\right)$ and higher WHC $(42.80 \%)$ was recorded with treatment $\mathrm{T}_{3}$ in which $70 \% \mathrm{NPK}+30 \% \mathrm{~N}$ through FYM were applied and lowest recorded with untreated control $\left(1.35 \mathrm{Mg} \mathrm{m}^{-3}\right.$ and $40.10 \%$, respectively). This can be ascribed to addition of higher organic matter through farmyard manure as compared to pressmud and vermicompost and increase in root biomass which helped in growth and development of soil microorganisms causing beneficial effect on improvement in mean weight diameter, available water capacity and hydraulic conductivity (Katkar et al., 2012).

The amount of available $\mathrm{N}$ content in soil gradually increased over the initial amount (205.7 $\mathrm{kg} \mathrm{ha}^{-1}$ ) at the harvest of crop irrespective of treatments (Table 2). The highest amount $\left(251.9 \mathrm{~kg} \mathrm{ha}^{-1}\right)$ of available $\mathrm{N}$ 
was recorded in the treatment where $70 \%$ recommended levels of NPK along with $15 \%$ $\mathrm{N}$ by FYM and rest $15 \%$ by pressmud $\left(\mathrm{T}_{8}\right)$ was applied which might be partly due to application of organic matter and fertilizer releasing nitrogen from mineralization (Gogoi et al., 2015) and partly due to releasing of native soil nitrogen. It might be due to the direct addition of $\mathrm{N}$ from the decomposition of organic matter leads to mineralization of organically bound nitrogen. The result was in agreement with the findings of many researchers (Chesti et al., 2013; Baishya et al., 2015).

The amount of available $\mathrm{P}$ and $\mathrm{K}$ in soil was varied between 24.14 to 37.38 and 143.2 to $186.0 \mathrm{~kg} \mathrm{ha}^{-1}$, respectively. The amount of both $\mathrm{P}$ and $\mathrm{K}$ were the highest in the treatment getting $70 \%$ RDF with $30 \% \mathrm{~N}$ by FYM and press mud equally $\left(\mathrm{T}_{8}\right)$. Such increase in $\mathrm{P}$ and $\mathrm{K}$ in soil might be explained by the release of $\mathrm{P}$ from the applied organic matter after mineralization and $\mathrm{K}$ due to releasing from organics and $\mathrm{K}$ bearing minerals that already present in alluvial soil. The higher value of available phosphorus was recorded in pressmud treated plots, which might be because pressmud is a rich source of phosphorus. Increasing soil available $\mathrm{P}$ with pressmud application in sugarcane was reported by Lakshmi et al., (2011). Singh et al., (2015) reported that organics were superior in improving available P. It might be due solubilizing effect of organic acids on organic phosphorus and organic anions retard the fixation of $\mathrm{P}$ in by complexing with organic ligands and chelation of $\mathrm{P}$ fixing cations like $\mathrm{Ca}, \mathrm{Mg}, \mathrm{Fe}, \mathrm{Al}, \mathrm{Zn}, \mathrm{Mn}$ and $\mathrm{Cu}$. Phosphorus complex with humic and fulvic acids increase the availability of phosphorus to the plants. However, in the present investigation there was a decline in available $\mathrm{K}$ content of soil from the initial value in all treatments except $\mathrm{T}_{6}$ and $\mathrm{T}_{8}$. This might be due to a gap between the removal and supplementation of $\mathrm{K}$ into the soil.
Insufficient addition of $\mathrm{K}$ through fertilizers, pressmud and vermicompost, and consequently higher removal by crops might be the possible reason of decrease in $\mathrm{K}$ availability in soil (Gogoi et al., 2015). The treatment $\mathrm{T}_{6}$ and $\mathrm{T}_{8}$ showed higher in available potassium than initial value. Such favourable effect of integrated nutrient management on increasing the available potassium content in soil were noticed by Baishya et al., 2015; Mondal et al., 2016. Similarly, available $\mathrm{S}$ in post harvest soil of rice also improved significantly from their initial value $\left(11.45 \mathrm{mg} \mathrm{kg}^{-1}\right)$ with integration of nutrient through organics and chemical fertilizer. The highest value $\left(16.0 \mathrm{mg} \mathrm{kg}^{-1}\right)$ of sulphur was recorded in $\mathrm{T}_{8}$. Build up of available $S$ could be justified as a result of mineralization of organic source that contributed to accumulation of more amount of $\mathrm{S}$ in soil and also through microbiological oxidation (Gogoi et al., 2015).

The amount of DTPA- extractable $\mathrm{Fe}, \mathrm{Mn}, \mathrm{Cu}$ and $\mathrm{Zn}$ content (Table 3) in soil did not followed similar trend changes to that of available $\mathrm{N}$ and $\mathrm{P}$ content in soil. The highest Fe content (42.90 mg kg $\mathrm{mg}^{-1}$ ) was recorded in $\mathrm{T}_{3}$. The Fe content was found to be higher in the treatments receiving fertilizers with FYM. It may be due to FYM has a good source of Fe as compared to other studied organics. Similar result was also reported by Hemalatha and Chellamuthu (2013). The higher $\mathrm{Cu}$ content $\left(2.49 \mathrm{mg} \mathrm{kg}^{-1}\right)$ recorded with $\mathrm{T}_{2}$ and in most of integrated treatments it was reduced from initial value $\left(2.31 \mathrm{mg} \mathrm{kg}^{-1}\right)$. The reduction was comparatively higher under FYM treatments. This might be due to the inverse relation of organic matter and $\mathrm{Cu}$ in soil (Singh et al., 2015). The highest Mn (12.06 mg kg $\mathrm{g}^{-1}$ ) with treatment $\mathrm{T}_{8}$. It may be due to the chelation of native Mn by organic matter (Hemalatha and Chellamuthu, 2013). The $\mathrm{Zn}$ content $\left(2.19 \mathrm{mg} \mathrm{kg}^{-1}\right)$ highest in treatment $\mathrm{T}_{5}$. Pressmud application increased the $\mathrm{Zn}$ availability after harvest of rice. The 
pressmud contains good amount of $\mathrm{Zn}$ and the effect of organic acids might help in increasing available $\mathrm{Zn}$ status (Singh et al., 2015).

Microbial biomass carbon and enzyme activities

Microbial biomass carbon (MBC) varied from $\sim 149$ to $218 \mu \mathrm{g} \mathrm{g}^{-1}$, with the highest value recorded under the $70 \% \mathrm{NPK}+15 \% \mathrm{~N}$ by FYM and rest $15 \%$ by pressmud $\left(\mathrm{T}_{8}\right)$ treatment and the least in the control plots (Table 4). The treatment in which $100 \%$ NPK $\left(\mathrm{T}_{2}\right)$ were applied which recorded significantly lower $\left(154 \mu \mathrm{g} \mathrm{g} \mathrm{g}^{-1}\right) \mathrm{MBC}$ as compared to $\mathrm{T}_{8}$ treatment.

Table.1 Effect of combined application of organics and chemical fertilizer on physico-chemical properties of soil

\begin{tabular}{|c|c|c|c|c|c|c|}
\hline Treatments & $\mathbf{p H}$ & $\begin{array}{c}\mathrm{EC} \\
\left(\mathrm{dS} \mathrm{\textrm {m } ^ { - 1 }}\right)\end{array}$ & $\begin{array}{l}\mathrm{OC} \\
(\%)\end{array}$ & $\begin{array}{c}\text { CEC } \\
{\left[\mathrm{Cmol}\left(\mathrm{p}^{+}\right) \mathrm{kg}^{-1}\right]}\end{array}$ & $\begin{array}{c}\text { BD } \\
\left(\mathrm{Mg} \mathrm{m}^{-3}\right)\end{array}$ & WHC (\%) \\
\hline $\mathbf{T}_{1}$ & $8.32 \mathrm{a}$ & $0.19 b$ & $0.36 b$ & $7.09 \mathrm{c}$ & $1.39 \mathrm{a}$ & $40.10 \mathrm{a}$ \\
\hline $\mathbf{T}_{2}$ & $8.26 a b$ & $0.21 \mathrm{ab}$ & $0.39 b$ & $8.14 a b c$ & $1.38 \mathrm{a}$ & $40.88 \mathrm{a}$ \\
\hline $\mathbf{T}_{\mathbf{3}}$ & $8.15 \mathrm{abc}$ & $0.24 \mathrm{ab}$ & $0.46 \mathrm{ab}$ & $8.60 \mathrm{abc}$ & $1.35 \mathrm{a}$ & $42.80 \mathrm{a}$ \\
\hline $\mathbf{T}_{4}$ & $8.20 \mathrm{ab}$ & $0.20 \mathrm{ab}$ & $0.41 \mathrm{ab}$ & $7.44 b c$ & $1.38 \mathrm{a}$ & $42.48 \mathrm{a}$ \\
\hline $\mathbf{T}_{5}$ & $7.93 c$ & $0.26 \mathrm{ab}$ & $0.43 \mathrm{ab}$ & $9.29 \mathrm{abc}$ & $1.38 \mathrm{a}$ & $42.62 \mathrm{a}$ \\
\hline $\mathbf{T}_{6}$ & $8.12 \mathrm{abc}$ & $0.25 \mathrm{ab}$ & $0.44 a b$ & $9.05 \mathrm{abc}$ & $1.36 \mathrm{a}$ & $41.64 \mathrm{a}$ \\
\hline $\mathbf{T}_{7}$ & $8.03 b c$ & $0.31 \mathrm{ab}$ & $0.45 \mathrm{ab}$ & $9.91 \mathrm{ab}$ & $1.37 \mathrm{a}$ & $42.15 \mathrm{a}$ \\
\hline $\mathbf{T}_{8}$ & $8.01 b c$ & $0.32 \mathrm{a}$ & $0.48 \mathrm{a}$ & $10.17 \mathrm{a}$ & $1.36 \mathrm{a}$ & $42.30 \mathrm{a}$ \\
\hline $\mathbf{T}_{9}$ & $8.05 \mathrm{bc}$ & $0.29 \mathrm{ab}$ & $0.46 \mathrm{ab}$ & $9.72 \mathrm{ab}$ & $1.37 \mathrm{a}$ & $42.23 \mathrm{a}$ \\
\hline
\end{tabular}

Means followed by same letter in each column are not significantly different by the Tukey HSD test $(\mathrm{P}<0.05)$.

Table.2 Effect of combined application of organics and chemical fertilizer on available macro nutrient status of soil

\begin{tabular}{ccccc}
\hline Treatments & $\mathbf{N}\left(\mathbf{k g ~ h a}^{-\mathbf{1}}\right)$ & $\mathbf{P}\left(\mathbf{k g ~ h a}^{-\mathbf{1}}\right)$ & $\mathbf{K}\left(\mathbf{k g ~ h a}^{-\mathbf{1}}\right)$ & $\mathbf{S}\left(\mathbf{m g ~ k g}^{\mathbf{- 1}}\right)$ \\
\hline $\mathbf{T}_{\mathbf{1}}$ & $200.7 \mathrm{~d}$ & $24.14 \mathrm{~d}$ & $143.2 \mathrm{~d}$ & $10.59 \mathrm{e}$ \\
$\mathbf{T}_{\mathbf{2}}$ & $219.1 \mathrm{c}$ & $30.26 \mathrm{c}$ & $164.3 \mathrm{c}$ & $11.36 \mathrm{e}$ \\
$\mathbf{T}_{\mathbf{3}}$ & $210.1 \mathrm{c}$ & $29.46 \mathrm{c}$ & $159.8 \mathrm{c}$ & $12.76 \mathrm{~d}$ \\
$\mathbf{T}_{\mathbf{4}}$ & $216.4 \mathrm{c}$ & $29.63 \mathrm{c}$ & $165.0 \mathrm{c}$ & $13.23 \mathrm{~cd}$ \\
$\mathbf{T}_{\mathbf{5}}$ & $231.0 \mathrm{~b}$ & $35.07 \mathrm{ab}$ & $161.1 \mathrm{c}$ & $16.58 \mathrm{a}$ \\
$\mathbf{T}_{\mathbf{6}}$ & $230.0 \mathrm{~b}$ & $31.95 \mathrm{bc}$ & $189.9 \mathrm{a}$ & $14.40 \mathrm{bc}$ \\
$\mathbf{T}_{\mathbf{7}}$ & $245.7 \mathrm{a}$ & $35.68 \mathrm{a}$ & $176.8 \mathrm{~b}$ & $16.00 \mathrm{a}$ \\
$\mathbf{T}_{\mathbf{8}}$ & $251.9 \mathrm{a}$ & $37.38 \mathrm{a}$ & $186.0 \mathrm{ab}$ & $15.42 \mathrm{ab}$ \\
$\mathbf{T}_{\mathbf{9}}$ & $244.6 \mathrm{a}$ & $34.75 \mathrm{ab}$ & $181.7 \mathrm{ab}$ & $14.63 \mathrm{~b}$ \\
\hline
\end{tabular}

Means followed by same letter in each column are not significantly different by the Tukey HSD test $(\mathrm{P}<0.05)$. 
Table.3 Effect of combined application of organics and chemical fertilizer on DTPA- extractable micronutrient status of soil

\begin{tabular}{ccccc}
\hline Treatments & $\mathbf{F e}\left(\mathbf{m g ~ k g}^{-\mathbf{1}}\right)$ & $\mathbf{C u}\left(\mathbf{m g ~ k g}^{-\mathbf{1}}\right)$ & $\mathbf{M n}\left(\mathbf{m g ~ k g} \mathbf{~}^{-\mathbf{1}}\right)$ & $\mathbf{Z n}\left(\mathbf{m g ~ k g}^{-\mathbf{1}}\right)$ \\
\hline $\mathbf{T}_{\mathbf{1}}$ & $22.97 \mathrm{f}$ & $1.65 \mathrm{de}$ & $7.12 \mathrm{~d}$ & $1.01 \mathrm{c}$ \\
$\mathbf{T}_{\mathbf{2}}$ & $33.53 \mathrm{e}$ & $2.49 \mathrm{a}$ & $8.41 \mathrm{~cd}$ & $1.41 \mathrm{bc}$ \\
$\mathbf{T}_{\mathbf{3}}$ & $42.90 \mathrm{a}$ & $1.33 \mathrm{e}$ & $9.74 \mathrm{bc}$ & $2.06 \mathrm{ab}$ \\
$\mathbf{T}_{\mathbf{4}}$ & $36.11 \mathrm{de}$ & $1.60 \mathrm{e}$ & $8.52 \mathrm{~cd}$ & $2.04 \mathrm{ab}$ \\
$\mathbf{T}_{\mathbf{5}}$ & $36.44 \mathrm{de}$ & $1.98 \mathrm{~cd}$ & $10.21 \mathrm{~b}$ & $2.19 \mathrm{a}$ \\
$\mathbf{T}_{\mathbf{6}}$ & $38.41 \mathrm{bcd}$ & $2.09 \mathrm{bc}$ & $9.88 \mathrm{bc}$ & $1.92 \mathrm{ab}$ \\
$\mathbf{T}_{\mathbf{7}}$ & $36.85 \mathrm{cde}$ & $2.47 \mathrm{a}$ & $10.57 \mathrm{ab}$ & $1.82 \mathrm{ab}$ \\
$\mathbf{T}_{\mathbf{8}}$ & $41.12 \mathrm{ab}$ & $2.35 \mathrm{ab}$ & $12.06 \mathrm{a}$ & $1.84 \mathrm{ab}$ \\
$\mathbf{T}_{\mathbf{9}}$ & $40.39 \mathrm{abc}$ & $1.41 \mathrm{e}$ & $10.59 \mathrm{ab}$ & $1.40 \mathrm{bc}$ \\
\hline
\end{tabular}

Means followed by same letter in each column are not significantly different by the Tukey HSD test $(\mathrm{P}<0.05)$.

Table.4 Effect of combined application of organics and chemical fertilizer on microbial biomass carbon and selected enzyme activities of soil

\begin{tabular}{|c|c|c|c|c|}
\hline Treatments & $\begin{array}{c}\mathrm{MBC} \\
\left(\mu \mathrm{g} \mathrm{g}^{-1}\right)\end{array}$ & $\begin{array}{c}\text { Urease } \\
\left(\mu \operatorname{urea~}^{-1} h^{-1}\right)\end{array}$ & 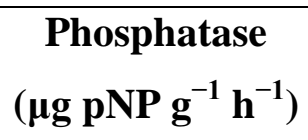 & $\begin{array}{l}\text { Dehydrogenase } \\
\left(\mu \mathrm{g} \text { TPF } g^{-1} d^{-1}\right)\end{array}$ \\
\hline$T_{1}$ & $149.3 \mathrm{e}$ & $169.8 d$ & $81.83 b$ & $27.07 b$ \\
\hline $\mathbf{T}_{2}$ & $154.0 \mathrm{de}$ & $179.4 \mathrm{~cd}$ & $102.3 \mathrm{ab}$ & $28.60 \mathrm{~b}$ \\
\hline $\mathbf{T}_{3}$ & $167.8 \mathrm{cde}$ & $189.8 \mathrm{bcd}$ & $105.0 \mathrm{a}$ & $38.07 \mathrm{a}$ \\
\hline $\mathbf{T}_{4}$ & $159.5 \mathrm{de}$ & $182.9 \mathrm{~cd}$ & $105.0 \mathrm{a}$ & $28.79 b$ \\
\hline $\mathbf{T}_{5}$ & $177.3 \mathrm{~cd}$ & 200.0abc & $116.2 \mathrm{a}$ & $38.82 \mathrm{a}$ \\
\hline $\mathbf{T}_{6}$ & $188.9 \mathrm{bc}$ & $196.5 b c$ & $108.5 \mathrm{a}$ & $38.31 \mathrm{a}$ \\
\hline $\mathbf{T}_{7}$ & 209.6ab & 214.0ab & $116.5 \mathrm{a}$ & $44.51 \mathrm{a}$ \\
\hline $\mathbf{T}_{8}$ & $218.2 \mathrm{a}$ & $221.9 \mathrm{a}$ & $121.5 \mathrm{a}$ & $43.31 \mathrm{a}$ \\
\hline $\mathbf{T}_{9}$ & $200.8 \mathrm{ab}$ & $210.1 \mathrm{ab}$ & $112.8 \mathrm{a}$ & $42.83 \mathrm{a}$ \\
\hline
\end{tabular}

Means followed by same letter in each column are not significantly different by the Tukey HSD test $(\mathrm{P}<0.05)$.

Increased microbial biomass carbon content recorded in the organically treated plots might be due to suitable conditions for microbial growth where, development had acted as a good substratum for microbial activity. An increase in microbial population by integrated use of FYM and inorganic fertilizer in a ricewheat system as compared to inorganic fertilizer alone was reported by Biswas et al.,
2007 and Kundu et al., 2016 and in soybean by Heidari et al., 2016. All soil enzymatic activities responded to the organic matter applied, but the response differed with dehydrogenase (Table 4). Compared with the $100 \%$ NPK $\left(\mathrm{T}_{2}\right)$ and untreated control $\left(\mathrm{T}_{1}\right)$ treatments, the organics treated soils showed higher activities of urease, alkaline phosphatase and dehydrogenase. The 
significantly highest activity of urease (221.9 $\mu \mathrm{g}$ urea $\mathrm{g}^{-1} \mathrm{~h}^{-1}$ ) reported with treatment $\mathrm{T}_{8}$, it was 23.7 higher over sole application of $100 \%$ NPK $\left(\mathrm{T}_{2}\right)$. Significantly lowest value $(169.8 \mu \mathrm{g}$ urea $\mathrm{g}^{-1} \mathrm{~h}^{-1}$ ) of urease enzyme activity noticed with unfertilized control. Urease activity of soil was found higher when recommended dose of NPK fertilizers were applied as compared to unfertilized control. It may be due to increase in activity of urease with addition of urea- $\mathrm{N}$ (Mishra et al., 2008). Urease activity was found to be increased with application of organic manures in combination with chemical fertilizers over application of chemical fertilizers alone as reported in several studies (Meena et al., 2014 and Lakshmi et al., 2014). Furthermore, the results of present study is consistent with the findings of Heidari et al., (2016) who indicated that organic manure had a positive effect on urease activity.

The highest activity of alkaline phosphatase

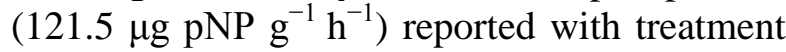
$\mathrm{T}_{8}$, it was reported $18.8 \%$ higher over sole application of $100 \%$ NPK $\left(\mathrm{T}_{2}\right)$. In alkaline phosphatase activity all integrated treatment reported statistically similar to each other. Chemical fertilizers suppressed the acid and alkaline phosphatase activity which can be explained through considering the fact that phosphatase synthesis is inhibited by available phosphorus (Wang et al., 2008). This increase in activity may be due to the release of more organically bound $\mathrm{P}$ due to faster decomposition of organic matter in presence of mineral $\mathrm{N}$ and $\mathrm{P}$ which stimulate the synthesis of the enzyme (Mohammadi et al., 2012). Dehydrogenase activity recorded higher (44.51 $\mu$ g TPF $\left.\mathrm{g}^{-1} \mathrm{~d}^{-1}\right)$ with treatment $T_{7}$, closely followed by $T_{8}$ and $\mathrm{T}_{9}$. However, in dehydrogenase activity the difference between integrated treatments was found nonsignificant. This might be due to the reason that sources of potential beneficial microbes in organic manures may possibly provide microbial diversity and activity of microorganisms accompanied by better dehydrogenase activity (Simon and Czako, 2014).

\section{References}

Baishya, L.K., Rathore, S.S., Singh, D., Sarkar, D. and Deka, B.C. 2015. Effect of integrated nutrient management on rice productivity, profitability and soil fertility. Annals of Plant and Soil Res., 17(1): 86-90.

Biswas, H., Rattan, R.K. and Singh, A.K. 2007. Effect of soil manipulation and resource management on carbon and nitrogen turnover under rice-wheat cropping system. J. Indian Soc. Soil Sci., 55(3): 276-284.

Black, C.A. 1965. "Methods of Soil Analysis: Part I Physical and mineralogical properties". American Society of Agronomy, Madison, Wisconsin, USA.

Casida, L.E., Jr Klein, D.A. and Santro, I. 1964. Soil dehydrogenase activity. Soil Sci., 98: 371-376.

Chesin, L. and Yein, C.H. 1950. Turbidimetric determination of available sulphur. Soil Sci. Society of America Proc., 15: 149151.

Chesti, M.H., Kohli, A. and Sharma, A.K. 2013. Effect of integrated nutrient management on yield of and nutrient uptake by wheat (Triticum aestivum) and soil properties under Intermediate Zone of Jammu and Kashmir. J. Indian Society of Soil Sci., 61(1): 1-6.

Douglas, L.A. and Bremner, J.M. 1971. A rapid method of evalutiny different compound as inhibitors of urease in soils. Soil Biology and Biochemistry 3: 309-15.

Gogoi, B., Kalita, B., Deori, B. and Paul, S.K. 2015. Soil properties under rainfed rice (Oryza sativa) crop as affected by integrated supply of nutrients. Int. J. Agri. Innovations and Res., 3(6): 1720-1725.

Heidari, G., Mohammadi, K. and Sohrabi, Y. 2016. Responses of soil microbial biomass and enzyme activities to tillage and fertilization systems in soybean (Glycine $\max$ L.) production. Frontiers in Plant Science, 7: $1730 . \quad$ doi: 10.3389/fpls.2016.01730 
Hemalatha, S. and Chellamuthu, S. 2013. Impacts of long term fertilization on soil nutritional quality under finger millet: Maize cropping sequence. J. Environ. Res. Develop., 7(4A), 1571-1576.

Jackson, M.L. 1973. Soil Chemical Analysis. Prentice Hall of India Pvt. Ltd., New Delhi.

Jat, L.K., Singh, Y.V. Meena, S.K.,Meena, S.K., Parihar, M., Jatav, H.S., Meena, R.K. and Meena, V.S. 2015. Does integrated nutrient management, enhance agricultural productivity? J. Pure and Appl. Microbiol., 9(2): 1211-1221.

Katkar, R.N., Kharche, V.K., Sonune, B.A., Wanjari, R.H. and Singh, M. 2012. Longterm effect of nutrient management on soil quality and sustainable productivity under sorghum-wheat crop sequence in Vertisoil of Akola, Maharashtra. Agropedol., 22(2): 103-114.

Kharche, V.K., Patil, S.R., Kulkarni, A.A., Patil, V.S. and Katkar, R.N. 2013. Longterm integrated nutrient management for enhancing soil quality and crop productivity under intensive cropping system on Vertisols. J. Indian Society of Soil Sci., 61(4): 323-332.

Kundu, D.K., Mazumdar, S.P., Ghosh, D., Saha, A.R., Majumdar, B., Ghorai, A.K. and Behera, M.S. 2016. Long-term effects of fertilizer and manure application on soil quality and sustainability of jute-ricewheat production system in IndoGangetic plain. J. Appl. Natural Sci., 8(4): 1793-1800.

Lakshmi, C.S.R., Sreelatha, T., Usha Rani, T., Rao, S.R.K. and Naidu, N.V. 2011. Effect of organic manures on soil fertility and productivity of sugarcane in north coastal zone of Andhra Pradesh. Indian J. Agri. Res., 45(4): 307-313.

Lindsay, W.L. and Norvell, W.A. 1978. Development of DTPA soil test for $\mathrm{Zn}$, Iron, Manganese and Copper. Soil Sci. Society of America J., 42: 421-428.

Mahajan, G.R., Manjunath, B.L., Singh, N.P., Ramesh, R.,Verma, R.R, Latare, A.M., D'Souza, R., Barnes, N. and Kulkarni, R.
2016. Effect of organic and inorganic sources of nutrients on soil microbial activity and soil organic carbon build-up under rice in west coast of India. Arch. Agronomy and Soil Sci., DOI: 10.1080/03650340.2016.1213813.

Meena, V.S., Maurya, B.R., Meena, R.S., Meena, S.K., Singh, N.P., Malik, V.K., Kumar, V. and Jat, L.K. 2014. Microbial dynamics as influenced by concentrate manure and inorganic fertilizer in alluvium soil of Varanasi, India. African J. Microbiol. Res., 8(3): 257-263.

Mohammadi, K., Heidari, G., Nezhad, M.T.K., Ghamari, S. and Sohrabi, Y. 2012. Contrasting soil microbial responses to fertilization and tillage systems in canola rhizosphere. Saudi J. Biol. Sci., 19(3): 377-383.

Mondal, S., Mallikarjun, M., Ghosh, M., Ghosh, D.C. and Timsina, J. 2016. Influence of integrated nutrient management (INM) on nutrient use efficiency, soil fertility and productivity of hybrid rice. Archives of Agronomy and Soil Sci., 1-9. DOI: 10.1080/03650340.2016.1148808

Olsen, S.R., Cole, C.V., Watanable, F.S. and Dean, L.A. 1954. Estimation of available phosphorus in soils by extraction with sodium bicarbonate USDA Circular 939.

Scotti, R., Bonanomi, G., Scelza, R., Zoina, A. and Rao, M.A. 2015. Organic amendments as sustainable tool to recovery fertility in intensive agricultural systems. J. Soil Sci. Plant Nutrition, 15(2): 333-352.

Sekhon, K.S., Singh, J.P. and Mehla, D.S. 2009. Soil organic carbon pools after seven years of manures and mineral fertilizers application in a rice-wheat rotation. Arch. Agronomy and Soil Sci., 55(2): 197-206.

Sharma, U. and Subehiya, S.K. 2014. Effect of long-term integrated nutrient management on rice (Oryza sativa L.) wheat (Triticum aestivum L.) productivity and soil properties in North -Western Himalaya. $J$. Indian Soc. Soil Sci., 62(3): 248-254.

Shukla, A.K., Sharma, S.K., Tiwari, R. and 
Tiwari, K.N. 2005. Nutrient depletion in the rice-wheat cropping system of the Indo-Gangetic plains. Better Crops, 89: 28-31.

Simon, T. and Czako, A. 2014. Influence of long-term application of organic and inorganic fertilizers on soil properties. Plant, Soil and Environ., 60(7): 314-319.

Singh, A.P., Mahapatra, B.S., Singh, R.K., Bhadadhwaj, A.K., Chaubey, A.K. and Vishwakarma, V.K. 2008. Productivity and fertility status in rice -wheat crop sequence as influenced by integrated nutrient supply under permanent plot experiment. J. Farming Systems Res. Develop., 14(1): 6-11.

Singh, B. and Singh, V. 2012. Productivity and fertility of soils in the Indo-Gangetic Plains of South Asia.Archives of Agronomy and Soil Sci., 58(sup1): S33S40.

Singh, G., Kumar, D. and Sharma, P. 2015. Effect of organics, biofertilizers and crop residue application on soil microbial activity in rice-wheat and rice-wheat mungbean cropping systems in the IndoGangetic plains. Cogent Geosci., 1(1): 1085296.

Sparks, D.L. 1996. Methods of soil analysis. Part 3- Chemical Methods. American Society of Agronomy, Inc., Soil Sci. Society of America, Inc. Madison Wisconsin, USA.

Srinivas, D., Bharatha Lakshmi, M. and Bhattacharyya, P. 2015. Carbon pools and associated soil enzymatic activities as influenced by long-term application of fertilizers and manure in lowland rice soil. J. Indian Society of Soil Sci., 63(3): 310-319.
Steinbergs, A. 1953. A rapid turbidimetric method for the determination of small amounts of sulfur in plant material. Analyst, 78: 47-53.

Su, Y.Z., Wang, F., Suo, D.R., Zhang, Z.H. and Du, M.W. 2006. Long-term effect of fertilizer and manure application on soilcarbon sequestration and soil fertility under the wheat-wheat-maize cropping system in northeast China. Nutrient Cycling in Agroecosystems, 75: 285-295

Subbiah, B. and Asija, G.L. 1956. Alkaline permanganate method of available nitrogen determination. Curr. Sci., 25: 259.

Sur, P., Mandal, M. and Das, D.K. 2010. Effect of integrated nutrient management on soil fertility and organic carbon in cabbage (Brassica oleracea var. capitata) growing soils. Indian J. Agri. Sci., 80(8): 38-41.

Tabatabai, M.A. and Bremner, J.M. 1969. Use of $p$-nitrophenyl phosphate for assay of soil phosphatise activity. Soil Biol. Biochem., 1: 301-307.

Tandon, H.L.S. 2001. Methods of Analysis of soils, plants, waters, and fertilizers. Fertilizer Development and Consultation Organization, New Delhi, India.

Vance, E.D., Brookes, P.C. and Jenkinson, D.S. 1987. Microbial biomass measurements in forest soils. The use of the chloroform fumigation incubation method in strongly acid soils. Soil Biol. Biochem., 19: 697702.

Wang, Q.K., Wang, S.L. and Liu, Y.X. 2008. Responses to $\mathrm{N}$ and $\mathrm{P}$ fertilization in a young Eucalyptus dunnii plantation: microbial properties, enzyme activities and dissolved organic matter. Appl. Soil Ecol., 40(3): 484-490.

\section{How to cite this article:}

Jat, L.K., and Singh, Y.V. 2017. Short-term Effects of Organic and Inorganic Fertilizers on Soil Properties and Enzyme Activities in Rice Production. Int.J.Curr.Microbiol.App.Sci. 6(2): 185-194. doi: http://dx.doi.org/10.20546/ijcmas.2017.602.025 